Ekmeleddin İhsanoğlu,

\title{
Osmanlı Bilim Mirası: Giriş, I. cilt: Mirasın Oluşumu, Gelişimi ve Meseleleri; II. cilt: Önemli Âlimler ve Eserler
}

İstanbul: Yapı Kredi Yayınları, 2017, xv+327+xviii+1181 s.,

ISBN: 978-975-08-4024-1

Osmanlı tarihi, Doğu'da ve Batı'da birçok bilim adamının ilgisini çekmiş ve yapılan araştırmalar neticesinde Osmanlı İmparatorluğu hakkında pek çok eser yazılmış, incelemeler yapılmıştır. Bu çalışmalar yapılırken Osmanlı İmparatorluğu’ nun siyasî tarihi ile idari, sosyal ve ekonomik yapıları kapsamlı bir şekilde ele alınmış ve gerek Doğu gerek Batı dillerinde yapılan bu çalışmalar yayınlanmıştır.

Fakat bu çalışmaların çokluğuna ve çeşitliliğine rağmen, Osmanlılar'da bilim ve bilim faaliyetleri, ciddi ilmî ilginin odağının dışında kalmıştır. Bu durum, Prof. Dr. Ekmeleddin İhsanoğlu’nun Osmanlı Bilim Mirası adlı kitabında da söz ettiği gibi İslâm'da ilim hayatının durumuyla ilgili olarak ileri sürülen Abbasi Devleti'nden sonra ilmî hayatın durakladığı ve gerilediği şeklindeki önyargılara bağlanmıştır. Bu önyargı, Osmanlı tarihiyle ilgilenenler arasında kabul görmüş ve tartışma kabul etmez bir gerçek gibi algılanıp bu sahada yapılan bütün çalışmaların etrafında döndüğü ön kabul hâline gelmiştir.

Bu bakımdan İhsanoğlu’nun “Osmanlı Bilim Mirası” gibi ilgi çekici bir başlıkla yayınladığı kitap, daha okunmaya başlamadan başlığıyla araştırmacıların zihnine pek çok soruyu getirmektedir: Osmanlı bilim mirası diye bir şey var mıdır? Eğer Osmanlı bilim mirasından söz edebiliyorsak bunun konuları nelerdir? Bu mirası oluşturan unsurlar nelerdir? Eğer Osmanlı bilim mirası varsa bu mirasın oluşmasını sağlayan kişiler yani Osmanlı bilim adamları olarak nitelendirilebilecek âlimler var mıdır? Şayet varsa bu bilim adamlarının bilime sağladıkları katkılar nelerdir? Ve yine bu bilim adamlarının Avrupadaki ilmî gelişmelere duydukları alaka ne düzeydedir? Bunlar Avrupa’daki ilmî gelişmelerden haberdarlar mıdır ve şayet haberdarlarsa bu gelişmeler karşısındaki tavırları ne yöndedir? Eğer bilim adamları Avrupa'daki ilmî gelişmelerden haberdarlarsa ve bu gelişmeleri Osmanlı ilim âlemine naklettilerse Osmanlı sultanlarının bu nakledilen yeni bilime karşı tutumları ne olmuştur? Ve daha bunun gibi pek çok soruyu, bu kitap sadece başlığıyla akla getirmekte, bir anlamda ortaya atmaktadır.

1500 sayfayı aşkın iki ciltlik bu devasa eser muhtevasıyla yukarıda sıraladığımız sorulara ve daha pek çok fazlasına kat'î delil ve burhanlara dayalı ilmî cevaplar 
sunmaktadır. Bu şekilde söz konusu çalışma, yazının başında ifade ettiğimiz dogmaya dönüşmüş iddiayı temelli bir şekilde çürütmektedir. Bu eser ayrıca bizi, Osmanlılar'da ve Osmanlı coğrafyasında bulunan İslâm dünyasındaki ilmî hayata dair meseleleri yeniden gözden geçirmeye sevk etmektedir. Kitabın birinci cildini oluşturan altı bahisten her biri, ilmî hayata dair bu sorgulamaların önemli kısımlarına cevap mahiyetindedir.

Kitap birinci bahisten dördüncü bahse kadar Osmanlılar'da bilim hayatının değişik vechelerini, kurumlarını ve literatürünü detaylı bir biçimde ortaya koymaktadır. Türklerin Anadolu topraklarını fethi, Türk-İslâm kültürünün yayılışı, Anadolu’da medreselerin kuruluşu, medreselerde aklî ilimlerin öğretilmesi, Anadolu’da Selçuklular ve Beylikler döneminde hastahaneler, yine aynı dönemde devlet adamlarının bilime gösterdikleri ilgi ve bu dönemde Anadolu’da yaşamış âlimlerden bazıları ve eserleri, Anadolu Selçukluları'nda astronomi ve astronomi âlimleri ve son olarak İslam bilim tarihinde güzide bir mevkii olan Merağa ekolünün Anadolu Selçuklu ve Osmanlı bilimine tesiri olmak üzere dokuz alt başlıktan oluşan birinci bahiste "Anadolu’da Osmanlı Öncesi İslâm Kültür ve Bilim Muhitinin Oluşması" ele alınmıştır. "Osmanlı Bilim Geleneğinin Doğuşunu" ele alan ikinci bahiste ise evvela Osmanlı sultanlarının bilime ve bilim adamlarına gösterdikleri himaye ve teşvik ile Osmanlı bilim adamlarının eski kültür merkezleri ile etkileşimleri ve mühtedilerin katkıları üzerinde durulmuş ve daha sonra belirli dönemlere göre tercüme hareketi detaylı bir biçimde ele alınarak Türkçenin bilim dili olarak gelişmesi hakkında önemli tespitlerde bulunulmuştur. Prof. Dr. İhsanoğlu "Osmanlı Eğitim ve Bilim Kurumları" başlı̆ıını taşıyan üçüncü bahiste bu kurumları evvela "Klasik Dönem” ve "Yenileşme Dönemi” olarak iki döneme ayırmış ve Klasik Dönemdekiler medreseler, vakıf ve Saraya bağlı kurumlar, İstanbul Rasathanesi; Yenileşme Dönemindekiler ise askerî ve sivil mühendislik eğitimleri, tıp mektepleri, Harp Okulu, Darülfünun ve son olarak yeni bilim kurumları ve modern ilmî metodolojinin başlaması olmak üzere her iki dönemin kendine has müesseselerini ayrı ayrı ele almıştır. Osmanlı bilim literatürüne toplu bir bakış sunan dördüncü bahiste ise Klasik Dönem ve Avrupa ile kurulan ilk temaslar üzerinde durulduktan sonra modern bilim literatüründen bahsedilmiştir.

"Osmanlı Biliminin Profili ve İstatistikî Değerler” başlıklı beşinci bahiste ise Osmanlı döneminde eser veren âlimler ile telif ve tercüme edilen eserler hakkında istatistikî bilgiler verilmiş, ayrıca bilim adamlarının coğrafi dağılımı gösterilmiştir. Bu bilgilere ilaveten bu bölümde eser istinsahlarıyla ilgili ilmî faaliyetler açıklanmış, Osmanlı bilim hayatının gelişme çizgileri, kaynakları ve konuları hem kronolojik 
hem coğrafi olarak ele alınmıştır. Osmanlı hâkimiyetinde gelişen bu faaliyetlerin istatistikî bilgilerle tahlili, bu dönemde bilim hayatının durakladığı veya donduğu şeklindeki önyargıyı temelsiz kılmaktadır. Bu tahlillerin gösterdiği önemli hakikatlerden biri de İstanbul'un, Osmanlı dünyası dâhil ve hâricinden bilim adamlarının çekim merkezi olduğu hususudur. Bu durumun, padişahların ve devlet adamlarının, ilim adamlarını himaye etmesi sayesinde oluştuğu anlaşılmakta ve padişahların, sırf siyasî bir motivasyonla hareket etmedikleri, fakat aynı zamanda ilim ve âlimleri himaye ettikleri görülmektedir. Ulaşılan bu neticeler, konuyla ilgili yeni araştırma ufuklarını açmaktadır.

$\mathrm{Bu}$ uzun soluklu çalışmanın ortaya koyduğu daha doğrusu keşfettiği ilk husus, çok yönlü ve zengin bir Osmanlı bilim mirasının varlığını göstermek olmuştur. Bu geniş bilim mirası, daha çok tıp, astronomi ve matematik gibi aklî ilimleri kapsamaktadır ve bu ilmî disiplinlerin Osmanlı Devleti'nin tarihi boyunca nasıl geliştiğini göstermektedir. Bu kitap Osmanlı bilim mirasının gelişme seyrini tesbit ederken kaynaklarının neler olduğunu göstermekte, hangi dillerde yazıldıklarını ortaya koymakta ve geniş Osmanlı coğrafyası dâhilinde farklı vilayetler arasındaki etkileşimleri de göstermektedir. Mesela Arap vilayetlerinde yazılan bazı eserlerin yazma nüshalarının sadece İstanbul kütüphanelerinde bulunduğunu biz bu kitapla görmüş oluyoruz. Bu eserde gösterilen yazmaların Osmanlı dünyasındaki dolaşımı ve buna ilaveten Osmanlı coğrafyasının dışına çıkışı, mesela bazı ilmî eserlere ait yazma nüshaların ancak Avrupa kütüphanelerinde olması da yine bu çalışma sayesinde dikkatimizi çeken hususlardandır.

Kitap altı bahsiyle ayrıca Osmanlı medresesinin bilimle ilgisini çok dakik bir şekilde göstermektedir. Bu da Osmanlı medreselerinde, münhasıran dinî ilimlerle ilgilienilip aklî ilimlerle ilgilenilmediğiyle ilgili iddiayı çürütmektedir. Bu kitap, değişik disiplinleriyle aklî ilimlerin gerek klasik dönemde gerek modernleşme döneminde Osmanlı medreselerindeki yerini göstermesi bakımından önemlidir. Yapılan tespitler, bu yönüyle medresenin, Osmanlı ilim hayatındaki rolünün yeniden değerlendirilmesini gerekli kılmaktadır; zira bu çalışma, Osmanlı medreselerinde iki dönemde de aklî ilimlerin gözardı edilmediğini ispatlamaktadır.

Kitabın altıncı bahsi ise konusunda ve Prof.Dr. İhsanoğlu’ nun yazıları arasında bir ilktir. Bu bölümde modernleşme döneminde, Osmanlı Devleti'nin modern bilimle ilgili tecrübesi; Rusya, Çin ve Japonya’nın tecrübeleriyle mukayese edilmektedir ve burada dört ülkenin tarihî bağlamı içinde ve batıdan modern bilimlerin aktarılması konusundaki kültürel ve sosyo-ekonomik şartlar, kurumların 
modernleştirilmesi hakkında oldukça başarılı tahliller sunulmaktadır. Bu tahlillerin sonunda İhsanoğlu, Osmanlı'da bilgi ve bilim konusunda modernleşmeden önce bir ilmî boşluk olmadığını, bilakis sahip olduğu ilim ve bilgi mirasının Osmanlı’yı, Batı'nın ürettiği bilim ve bilgi karşısında seçici bir tavra sevk ettiğini göstermektedir.

Prof.Dr. İhsanoğlu bu kitapta daha önce yayınlamış olduğu ve 52 ülkede bulunan 527 yazma eser koleksiyonunun taranması sonucunda ortaya çıkan 18 ciltlik geniş kapsamlı literatürün özetini sunmaktadır ve burada Osmanlı coğrafyası içinde ve dışında yetişen Osmanlı âlimlerini besleyen kaynakları ortaya koymaktadır. Bu kaynaklar, Osmanlılar'ın ırkî veya dinî farklılıkları nazar-1 itibara almadıklarını göstermekte ve çalışmada, Mısır, Irak, Suriye, Tunus, Kuzey Afrika, İran, Orta Asya ve Avrupa menşeli âlimler ile Endülüs'ten gelen Müslüman ve Musevi âlimlerin, Osmanlı ilim hayatına ve dolayısıyla Osmanlı bilim mirasına katkılarının olduğunu gözler önüne sermektedir.

Kitap, Osmanlı bilim mirasını oluşturan binlerce yazma eseri, bulundukları kütüphanelere varana kadar tüm teknik detaylarıyla dakik bir şekilde tespit etmektedir. Bu tafsilatlı bilgiler, çalışmayı temel bir kaynak hâline getirmiştir. Hatta tespit edilen her bir eserin dünya kütüphanelerindeki nüshalarının bulunmuş ve detaylı bir şekilde tavsif edilmiş olması sebebiyle bu kitabın 14. asırdan 20. asra kadar İslâm bilim mirasının vesikası hâline geldiğini söylemek mümkündür. Aynı eserin değişik kütüphanelerde bulunan nüshalarının belirlendiği bu kitapta, ayrıca zikredilen bazı eserlerin Berlin'de, Rodos'ta ve Londra'daki British Library'de bulunan nadir nüshaları da belirtilmiş, bunun yanısıra Fethullah el-Şirvânînnin Şerhü'l-Mulabhas fìl-Heye ve Ali Kuşçu'nun Risale fî̀ İlmi'l-Heye adlı eserleri gibi tek nüshası olan eserlere de yer verilmiştir.

Genel olarak İslâm bilim mirası veya özel olarak Osmanlı bilim mirasına münhasır kalmayan bu kitap, Osmanlı Devleti'nin sona erişinden sonra ortaya çıkan ve siyasî, sosyal ve kültürel olarak Osmanlı dokusunun birer parçası olan devletlerde ve özellikle Arap dünyası ülkelerindeki ilmî faaliyetler açısıdan da önem kazanmaktadır. Osmanlı dünyasının bir parçası olan bu yeni ülkelerde Osmanlı çerçevesinde kalan ilmî faaliyetlerin Osmanlı bilim mirasıyla nasıl etkileştiğini, ne alıp verdiğini göstermesi bakımından da bu kitap, bir çok Avrupalı veya Arap araştırmacının ileri sürdüğg̈ gibi bir durgunluktan bahsedilemeyeceğini ispat etmektedir. Muhammed el-Mansurî el-Tunusînin tıp konusundaki eseri, Zekeriyya el-Ensarî el-Masrî̀nin Tubfetürr-Râgılbîn adlı ve Abdülvâhid el-Magribînnin Minhatüll-Hâcib veTuhfetü'l-Mubib adlı eserleri gibi Arapça bilim yazmaları açısından çok zengin 
bir kaynak oluşturan çalışma, Türk kütüphanelerinde bulunup da başka yerde bulunmayan eserler hakkında araştırmacılara bilgi vermekte ve bu yönüyle de büyük kolaylık sağlamaktadır.

Netice itibariyle bu kitap, tarih araştırmalarına büyük bir katkı sağlayarak Osmanlı bilim mirasının varlığını delilleriyle göstermiştir. Kendine has bir seyir süreci olan bu miras, Şark'a ve Garp'a ait değişik kaynaklardan beslenmiştir. Bu husus, hem klasik hem modernleşme dönemlerinin her safhasında gerçekleşen tercüme faaliyetleriyle İslâm medeniyet merkezleri ve Avrupa'daki ilim üretim merkezleri arasında kültürel etkileşim olduğunu göstermektedir. Ayrıca bu bilim mirasının tam bir resmini ortaya koyan bu eser, sırf Türkçe yazılan eserler üzerinde durmayarak İslâm kültürünün üç dili olan Arapça, Türkçe ve Farsça yazılan eserlerin tamamının çalışmalarda göz önünde bulundurulması gerektiğini de uygulamalı olarak göstermiş olmaktadır. Osmanlı mirasının muhtevasıyla ilgili yeni bir vizyon sunan çalışma, bilim mirasının coğrafi ufukları ile dil ufuklarını genişletmektedir. Bu, çalışmadaki şu ifadeyle belirlenmektedir: "Osmanlı bilimi, Osmanlı Devleti'nin mekân ve zaman boyutları içinde oluşan ilmî faaliyetleri kapsar. Osmanlı Devleti'nin altı asırlık tarihi boyunca imparatorluk sınırları içerisinde görülen bilim hareketleri, kendine has bir gelişme çizgisi göstermiştir.' Böylece çalışma Arap ve Rumeli vilayetlerindeki ilmî faaliyetleri de kapsamaktadır. Ayrıca Osmanlılar'ın modern bilimle ilişkileri konusunda yeni bir vizyon getiren kitap, Osmanlılar'ın erken dönemden itibaren Avrupa'daki ilmî faaliyetlerden ve gelişmelerden haberdar olduklarını, erken dönemde Batı dillerinden yapılan tercümelerle ortaya koymaktadır. Aynı zamanda devletin resmî kurumlarının, ulemanın ve toplumun aklî ilimler ve din konusundaki tavırları hakkında açık bir görüş belirtmektedir. Beşinci bahiste yer alan istatistikî cetveller ve onlarla ilgili analitik tespitler, Osmanlı araştırmaları sahasında bu konuda bir ilktir. Böylece kitap yeni ve mühim sonuçlar sunmuş olmaktadır.

Bu kitap, tüm bu anlatılanlar sayesinde araştırmacıların önüne yeni ufuklar açmakta ve onları daha derin ve yeni konulara yönlendirmektedir. Doğu'da ve Batı'da Osmanlı bilimi konusunda yeni değerlendirmelerle dinamizm yaratan bu eserin, fikir hayatı ve devletin bilimle ilişkisi konusunda yeni bir sayfa açtığını söylemek mübalağa olmayacaktır. 